\title{
Onset and Duration of Luteal Activity Postpartum and Their Effect on First Insemination Conception Rate in Lactating Dairy Cows
}

\author{
Abdelrahim HOMMEIDA ${ }^{1)}$, Toshihiko NAKAO ${ }^{2) *}$ and Hirokazu KUBOTA ${ }^{3)}$ \\ ${ }^{1)}$ Laboratory of Animal Science, Graduate School for International Development and Cooperation, Hiroshima University, 1-5-1 \\ Kagamiyama, Higashi-Hiroshima 739-8529, ${ }^{2}$ Department of Veterinary Medicine, Faculty of Agriculture, Yamaguchi University, \\ Yoshida 1677-1, Yamaguchi 753-8515 and ${ }^{3}$ Setouchi Field Science Centre Experimental Farm, Graduate School of Biosphere Science, 2 \\ Kagamiyama, Higashi-Hiroshima 739-0046, Japan
}

(Received 25 November 2004/Accepted 23 June 2005)

ABSTRACT. The incidence of different types of luteal activity postpartum and their effect on reproductive performance were studied in 21 postpartum dairy cows. Progesterone concentrations in defatted milk collected 3 times a week were determined by EIA. Reproductive tract examination was undertaken every other week postpartum. Body weight and body condition score (BCS) were measured before and after calving and the average 100-day milk yield was calculated. Nine (42.9\%) cows had normal ovarian activity (first luteal activity $\leq 50$ days postpartum followed by regular cycles), 5 (23.8\%) had prolonged luteal phase (PLP; ovarian cycle with luteal activity $\geq 20$ days pre-service) and in 7 (33.3\%) cows the first luteal activity was shown later than 50 days postpartum (DOV). When compared with normal cows, both PLP and DOV had longer interval to first insemination (63.1 \pm 22.0 days versus $77.6 \pm 21.6$ and $93.0 \pm 22.3$ days, $\mathrm{P}<0.05$ and $\mathrm{P}<0.01$, respectively), lower first insemination conception rate $(88.9 \%$ versus $0.0 \%$ and $57.1 \%, \mathrm{P}<0.01$ and $\mathrm{P}<0.05$, respectively) and greater BCS loss $(0.81 \pm 0.2$ versus $1.05 \pm 0.21$ and $1.04 \pm 0.10$, respectively, $\mathrm{P}<0.01)$. Cows with PLP showed longer interval to uterine involution than normal and DOV groups (54.0 \pm 8.3 days versus $42.4 \pm 5.5$ and $43.3 \pm 8.3$ days, respectively, $\mathrm{P}<0.01)$ and higher 100-day milk yield ( $38.8 \pm 2.7 \mathrm{~kg}$ versus $33.6 \pm 4.7$ and $29.9 \pm 6.1 \mathrm{~kg}$, respectively, $\mathrm{P}<0.01)$. In conclusion, more than half of the cows had abnormal luteal activity postpartum, which adversely affected reproductive performance.

KEY WORDS: dairy cow, luteal activity, postpartum.

J. Vet. Med. Sci. 67(10): 1031-1035, 2005

In dairy cows once a year calving has been generally accepted as optimum to derive maximum economic benefit [5]. To attain this goal, cows should resume normal ovarian activity within a few weeks after calving and conceive within 85 days after parturition [23]. Recent increased genetic capability for milk production has been associated with reduced fertility in dairy cows [11]. Failure of the ovary to resume ovulation has been reported to increase in cows selected for milk production than traditional cows [9, 16]. In addition a high incidence of prolonged luteal activity was recently demonstrated by some investigators $[14,19]$. The negative energy balance (NEB) the cow suffers during early lactation has been suggested as an underlying cause for reduced fertility in high milk producers. Greater NEB during the first 30 days postpartum delayed first ovulation [4] and might exert a carryover effect on corpus luteum function after breeding [24]. However, the importance of prolonged luteal phase as an abnormal resumption of ovarian activity has not been well described. The objectives of this study were to describe various types of postpartum ovarian activity including prolonged luteal phase in lactating dairy cows and their influence on the subsequent reproductive performance.

\footnotetext{
* Correspondence to: NaKao, T., Department of Veterinary Medicine, Faculty of Agriculture, Yamaguchi University, Yoshida 1677-1, Yamaguchi 753-8515, Japan.
}

\section{MATERIALS AND METHODS}

Animals: This study was carried out in 21 Holstein-Friesian cows in their first to seventh lactations at Setouchi Field Science Center Experimental Farm, Hiroshima University between December 2002 and February 2004. The cows were kept in free stalls and fed a ration consisting of hay, silage and concentrates prepared to meet their production requirements.

Milk samples collection and progesterone assay: Starting from the 2nd week postpartum milk samples were collected three times a week (Monday, Wednesday and Friday) until the cows either returned to estrus or were diagnosed pregnant after first insemination. Milk fat was separated by centrifugation at $1,700 \times \mathrm{g}$ for $30 \mathrm{~min}$ and the defatted milk was stored in $4-\mathrm{m} l$ plastic tubes at $-30^{\circ} \mathrm{C}$ until assay. Progesterone was assayed in defatted milk samples in duplicate by enzyme immunoassay [26]. The intra-assay and inter-assay coefficients of variation were $4.0 \%$ and $7.8 \%$, respectively. The sensitivity of the test was $0.05 \mathrm{ng} / \mathrm{m} l$ and the recovery rate of the assay ranged between 86 to $110 \%$. The onset of luteal activity was considered when defatted milk progesterone concentration reached to $0.5 \mathrm{ng} / \mathrm{m} l$ or higher (equivalent to $5.0 \mathrm{ng} / \mathrm{m} l$ or higher whole milk progesterone concentration) and remained for at least three consecutive samples.

Postpartum reproductive tract examination: The reproductive tract and ovaries were examined by vaginoscopy and palpation per rectum at 2-week interval until the 11th week postpartum. Vaginoscopy was done using a glass 
speculum. Condition of vagina and cervix, and presence and type of discharge were recorded. Uterine involution was considered complete when the size of both uterine horns was similar. Body condition score (BCS) using a five-point scale [6] and body weight using a weight scale (Takara Scale, Yamaguchi, Japan) were taken from within one week prepartum and at 2-week interval until the 11 th week postpartum. The average milk yield for the first 100 days postpartum was recorded.

Estrus detection and artificial insemination: Heat detection, based on visual observation and use of heat mount detector (HMD) (Kamar Heatmount Detector ${ }^{\circledR}$, Kamar, Inc., Steamboat Spring Co., U.S.A.) as an estrus detection aid, was conducted starting on 40-day voluntary waiting period. Cows were observed 3 times a day, at 06:00, 14:00 and 22:00 hr, for at least $30 \mathrm{~min}$ each and any secondary estrous signs and/or standing activity were recorded. Estrus was defined when cow stood to be mounted or when the color of HMD turned uniformly red. When detected in estrus, cows were inseminated artificially by recto-vaginal method by an experienced AI technician. Inseminations were carried out after spontaneous estrus for all cows, except three (one in normal and two in PLP categories) in which estrus was induced with $\mathrm{PGF}_{2 \alpha}$ analogue $\left(25 \mathrm{mg}\right.$ of Pronalgon ${ }^{\circledR} \mathrm{F}$ Injection, Pharmacia, Tokyo, Japan). Pregnancy was diagnosed by palpation per rectum 35 days after first insemination or later.

Statistical analysis: Intervals to completion of uterine involution, first progesterone rise, first insemination, averaged 100-day milk yield; and BCS and body weight among the categories were compared with ANOVA and differences determined using Duncan's Multiple Range Test. Chi square test was used to compare conception rates.

\section{RESULTS}

Incidence of different types of luteal activity postpartum: In this study, $6(28.6 \%)$ of 21 cows showed short luteal phase (less than 10 days) after first ovulation that followed by regular cycles of normal duration. All of these cows were later included in the normal category. Applying the criteria used in previous studies [14, 19] to define luteal activity postpartum, nine (42.9\%) of the cows showed normal ovarian activity with first luteal activity detected $\leq 50$ days postpartum that was followed by regular cycles, whereas $12(57.1 \%)$ showed abnormal activity. Out of the cows with abnormal patterns, $5(23.8 \%)$ had prolonged luteal phase (PLP; one or more ovarian cycles with luteal activity $\geq 20$ days pre-service) and $7(33.3 \%)$ had delayed first ovulation (DOV; first luteal activity was not detected until $>50$ days postpartum) (Table 1$)$.

Reproductive performance: The cows under the study had their first progesterone rise on average at $43.0 \pm 18.4$ days postpartum and they were first inseminated artificially at $76.5 \pm 24.8$ days. Fertility parameters for the different categories are summarized in Table 2. Delayed ovulation category cows had longer interval to first insemination than both PLP $(\mathrm{P}<0.05)$ and normal cows $(\mathrm{P}<0.01)$. In PLP category cows, although they ovulated earlier postpartum (30.0 \pm 12.4 days), they still showed a significantly longer $(\mathrm{P}<0.05)$ interval to first insemination than normal cows. None of the cows in PLP category conceived after first insemination.

Table 1. Classification and incidence of different categories of postpartum luteal activity in dairy cows

\begin{tabular}{llcc}
\hline Category & Definition & Number & Percentage \\
\hline Normal & $\begin{array}{l}\text { First luteal activity was detected } \leq 50 \text { days } \\
\text { postpartum that followed by regular cycles }\end{array}$ & $9^{1)}$ & 42.9 \\
$\begin{array}{l}\text { Abnormal } \\
\quad \text { Prolonged luteal phase (PLP) }\end{array}$ & $\begin{array}{l}\text { One or more ovarian cycles with luteal } \\
\text { activity } \geq 20 \text { days pre-service }\end{array}$ & 5 & 28.3 \\
$\quad$ Delayed ovulation (DOV) & $\begin{array}{l}\text { First luteal activity was not detected until } \\
\text { >50 days postpartum }\end{array}$ & 7 & 33.3 \\
$\quad$ Subtotal & & 12 & 57.1 \\
Total & 21 & 100 \\
\hline
\end{tabular}

1) Six of the 9 cows showed a short luteal phase after first ovulation postpartum.

Table 2. Reproductive performance of dairy cows having normal, prolonged or delayed postpartum luteal activity

\begin{tabular}{lcccc}
\hline \multirow{2}{*}{ Reproductive performance } & \multicolumn{3}{c}{ Resumption of luteal activity group ${ }^{1)}$} \\
\cline { 2 - 5 } & Normal & PLP & DOV & Average \pm SD \\
\hline Number of cows & 9 & 5 & 7 & \\
First progesterone rise (d) & $33.4 \pm 9.0^{\mathrm{a}}$ & $30.0 \pm 12.4^{\mathrm{a}}$ & $64.7 \pm 9.3^{\mathrm{c}}$ & $43.0 \pm 18.4$ \\
Interval to complete uterine involution (d) & $42.4 \pm 5.5^{\mathrm{a}}$ & $54.0 \pm 8.3^{\mathrm{c}}$ & $43.3 \pm 8.3^{\mathrm{a}}$ & $45.5 \pm 8.4$ \\
Interval to first insemination (d) & $63.1 \pm 22.0^{\mathrm{a}}$ & $77.6 \pm 21.6^{\mathrm{b}}$ & $93.0 \pm 22.3^{\mathrm{c}}$ & $76.5 \pm 24.8$ \\
First insemination conception rate & $88.9 \%^{\mathrm{a}}$ & $0.0 \%^{\mathrm{c}}$ & $57.1 \%^{\mathrm{b}}$ & $57.1 \%$ \\
\hline
\end{tabular}

Results are expressed as means \pm SD. Means in the same row with different superscripts $(a, b$ and $c)$ differed significantly, a, b and $\mathrm{b}, \mathrm{c}=\mathrm{P}<0.05$, and $\mathrm{a}, \mathrm{c}=\mathrm{P}<0.01$.

1) For definition, see Table 1. 

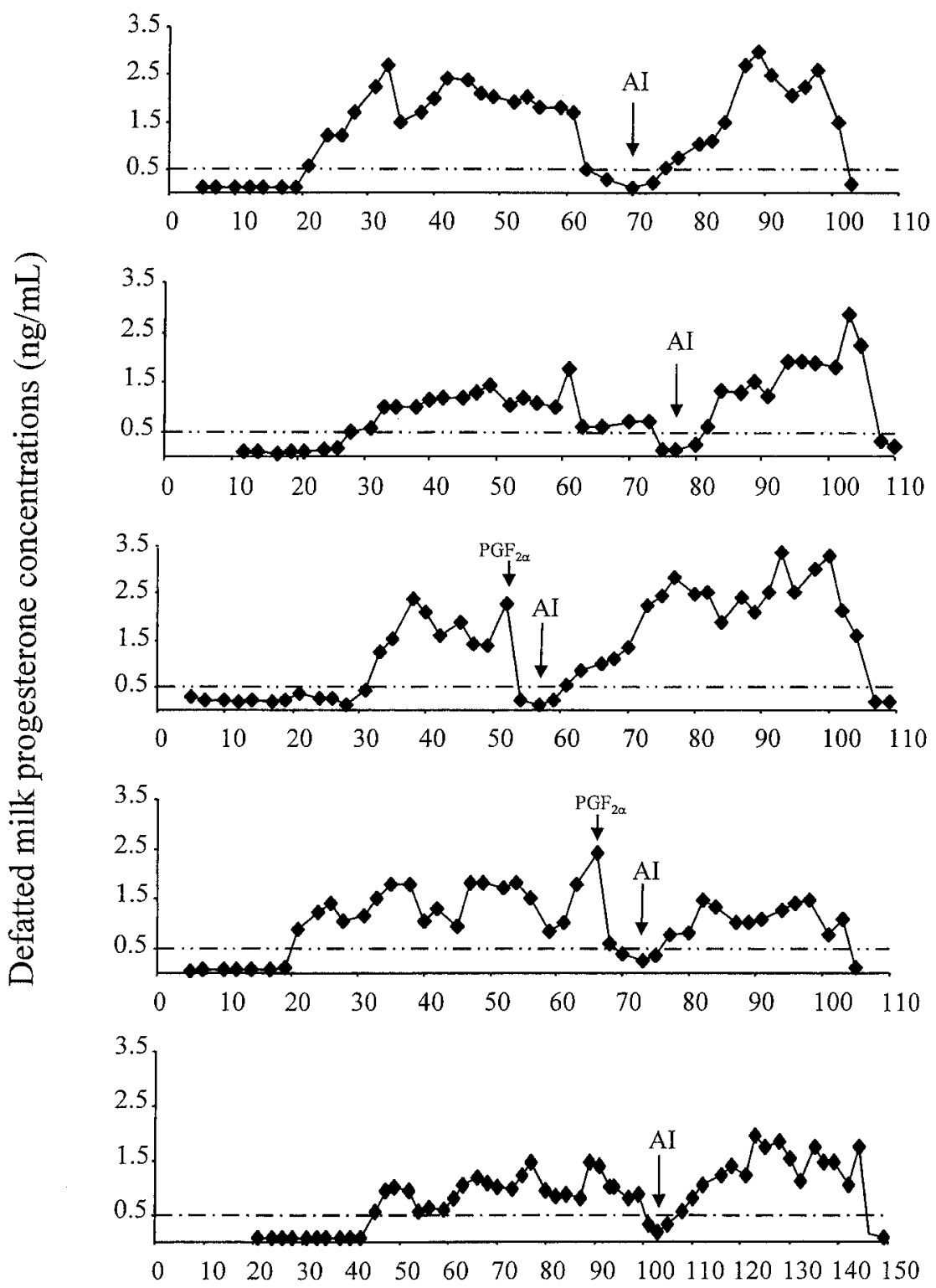

Days postpartum

Fig. 1. Defatted milk progesterone profiles in cows with prolonged luteal phase after first ovulation postpartum and after first insemination.

All the 5 cows repeated the prolonged luteal phase after first insemination (Fig. 1). Cows with PLP had the longest interval to completion of uterine involution postpartum $(\mathrm{P}<0.01)$. Purulent vaginal discharges were detected 19 to 21 days postpartum in three (14.3\%) cows, one in PLP and two in DOV categories.

Production parameters: Cows with PLP had a higher100day milk yield than cows in normal and DOV categories $(\mathrm{P}<0.01)$. Both PLP and DOV category cows experienced a greater loss in $\mathrm{BCS}$ than normal cows $(\mathrm{P}<0.01)$. No differ- ence was observed in body weight loss among categories (Table 3).

\section{DISCUSSION}

In this study the appearance of first progesterone rise postpartum occurred on average at 43.0 days postpartum which was much later, when compared to earlier reports [2, $7]$, but not far from those reported recently $[11,14]$. This supports the idea that first postpartum ovulation in the mod- 
Table 3. Production parameters of dairy cows having normal, prolonged or delayed postpartum luteal activity

\begin{tabular}{lcccc}
\hline \multirow{2}{*}{ Production parameters } & \multicolumn{4}{c}{ Resumption of luteal activity group } \\
\cline { 2 - 5 } & Normal & PLP & DOV & Average \pm SD \\
\hline Number of cows & 9 & 5 & 7 & \\
BCS at calving & $3.42 \pm 0.12$ & $3.50 \pm 0.18$ & $3.46 \pm 0.19$ & $3.45 \pm 0.15$ \\
BCS loss ${ }^{2}$ & $0.81 \pm 0.2^{\mathrm{a}}$ & $1.05 \pm 0.2^{\mathrm{c}}$ & $1.04 \pm 0.1^{\mathrm{c}}$ & $0.94 \pm 0.2$ \\
Body weight at calving (kg) & $701.2 \pm 60.9$ & $748.8 \pm 48.1$ & $714.1 \pm 105.9$ & $717.0 \pm 73.4$ \\
Body weight loss ${ }^{3)}$ & $15.8 \pm 4.2$ & $14.8 \pm 3.5$ & $19.8 \pm 4.7$ & $16.8 \pm 4.4$ \\
Lactation number & $3.2 \pm 1.8$ & $4.0 \pm 1.9$ & $2.3 \pm 1.6$ & $3.1 \pm 1.8$ \\
Daily milk yield (kg) within 100-d in milk & $33.6 \pm 4.7^{\mathrm{a}}$ & $38.8 \pm 2.7^{\mathrm{c}}$ & $29.9 \pm 6.1^{\mathrm{a}}$ & $33.6 \pm 5.8$ \\
\hline
\end{tabular}

Results are expressed as means \pm SD. Means in the same row with different superscripts (a, c) differed significantly; $\mathrm{a}, \mathrm{c}=\mathrm{P}<0.01$.

1) For definition, see Table 1.

2) As difference between BCS at calving and nadir of BCS postpartum.

3) As percentage of body weight at calving.

ern, high-yielding dairy cows tends to occur later than it did in previous decades. Short luteal phase, with comparatively lower progesterone concentrations, were reported to occur naturally following first ovulation in dairy cows [8, 22] and was found to be associated with $\mathrm{PGF}_{2 \alpha}$ secretion [8]. The incidence of DOV (33.3\%) was greater than earlier reports $[9,12,14,19]$, whereas the incidence of PLP was similar to that reported by Opsomer et al. [14]. The incidence of clinical endometritis $(14.3 \%)$, as indicated by purulent discharge, was lower than the report by Nakao et al. [12], who reported $44.0 \%$ and $32.0 \%$ in high- and medium- producing dairy cows raised in commercial farms in Hokkaido, Northern Japan. This could be attributed to the better hygienic and sanitary measures usually undertaken in experimental versus commercial farms. Moreover, managing cows in large herds was reported to increase the risk for uterine infection [11].

Cows in both categories of abnormal ovarian activity had shown an increased interval to first insemination, which is similar to previous reports $[12,20]$. Delaying the time to first insemination will increase calving interval beyond 12 months that considered optimum for profitability of dairy farming.

Cows with PLP had shown the most detrimental effect on conception rate that none of the cows in this group conceived after first insemination. Moreover, all these cows had repeated the prolonged luteal phase after insemination. In cycling cows, it has been proposed that estradiol from developing preovulatory follicle triggers the release of hypophysial oxytocin, which, in turn, stimulates release of a small quantity of uterine $\mathrm{PGF}_{2 \alpha}$. Prostaglandin $\mathrm{F}_{2 \alpha}$ then initiates a positive feed back loop involving release of luteal oxytocin and $\mathrm{PGF}_{2 \alpha}$ from the uterus. Prostaglandin $\mathrm{F}_{2 \alpha}$ is then transported locally to the adjacent ovary to cause luteolysis [21]. Any condition that interferes with the secretion or local transportation of $\mathrm{PGF}_{2 \alpha}$ from the uterus can cause delay or prevent luteolysis. Clinical or subclinical uterine infection or other uterine pathological problems may compromise the uterine ability to produce or transport $\mathrm{PGF}_{2 \alpha}$ 13]. This is likely to be one of the factors predis- posed to PLP in this study as indicated by the delayed uterine involution in this group. In addition, cows with PLP showed the highest average100-day milk yield among the groups and a significant greater loss in BCS than normal cows. Specific physiological mechanisms that may predispose higher milk producers to have higher incidence of prolonged luteal phase are not clear. Inadequate plasma estradiol concentrations were reported to be associated with prolonged luteal phase [25]. Increased dry matter intake associated with high milk production reduced estradiol concentration, may be through enhancing estradiol clearance rate $[17,18]$. Moreover, follicles in cows affected with severe negative energy balance (greater BCS loss) were reported to be smaller in size and produce less estrogen [1]. However, some studies indicated that the occurrence of PLP has not been associated with any obvious clinical reproductive disorders $[3,14]$. A high incidence of prolonged luteal phase after insemination in cows with prolonged luteal activity after first ovulation was reported previously [9]. Prolonged luteal phase after insemination may indicate embryonic or fetal loss [9, 10]. It seems that a suboptimal uterine environment, which possibly had interfered with luteolysis in these cows, was detrimental to the later embryo survival.

Mean BCS in all groups before parturition was in a desirable range. However, BCS loss was greater in DOV category cows than in normal cows. A decrease in BCS during the first and second months after calving has been found to be an important risk factor for delayed ovulation [15]. Negative energy balance is known to inhibit follicular development and delay resumption of ovarian activity [4].

In conclusion, more than half of the cows had abnormal postpartum resumption of ovarian activity, which influenced reproductive performance by increasing interval to first insemination and reducing conception rate to first insemination.

ACKNOWLEDGMENTS. This study was supported in part by Japan Livestock Technology Association and Morinaga Foundation. The first author was supported by Mon- 
bukagakusho Scholarship of Ministry of Education, Culture, Sports, Science and Technology, Japan.

\section{REFERENCES}

1. Beam, S. W. and Butler, W. R. 1999. Effects of energy balance on follicular development and first ovulation in postpartum dairy cows. J. Reprod. Fertil. (Suppl.) 54: 411-424.

2. Bulman, D. C. and Lamming, G. E. 1978. Milk progesterone levels in relation to conception, repeat breeding and factors influencing acyclicity in dairy cows. J. Reprod.Fertil. (Suppl.) 54: 447-458.

3. Bulman, D. C.and Lamming, G. E. 1977. Cases of prolonged luteal activity in the non-pregnant dairy cow. Vet. Res. 100: 550-552.

4. Butler, W. R. 2000. Nutritional interactions with reproductive performance in dairy cattle. Anim. Reprod. Sci. 60: 449-457.

5. Dijkhuizen, A. A., Stelwagen, J. and Renkima, J. A. 1985. Economic aspects of reproductive failure in dairy cattle: 1 . Financial loss at farm level. Prev. Vet. Med. 3: 251-263.

6. Ferguson, J. D., Galligan, D. T. and Thomsen, N. 1994. Principal descriptors of body condition score in Holstein cows. $J$. Dairy. Sci. 77: 2695-2703.

7. Fonseca, F. A., Britt, J. H., McDaniel, B. T., Wilk, J. C. and Rakes, A. H. 1983. Reproductive traits of Holsteins and Jerseys. Effect of age, milk yield, and clinical abnormalities on involution of cervix and uterus, ovulation, estrous cycles, detection of estrus, conception and days open. J. Dairy. Sci. 66: $1128-1147$.

8. Hunter, M. G., Characteristics and causes of inadequate corpus luteum. 1991. J. Reprod. Fertil. 43: 91-99.

9. Lamming, G. E. and Darwash, A. O. 1998. The use of milk progesterone profiles to characterise components of sub-fertility in milked dairy cows. Anim. Reprod. Sci. 52: 175-190.

10. Lamming, G. E., Darwash, A. O. and Back, H. L. 1989. Corpus luteum function in dairy cows and embryo mortality. $J$. Reprod. Fertil. (Suppl.) 37: 245-252.

11. Lucy, M. 2001. Reproductive loss in dairy cattle: where will it end? J. Dairy. Sci. 84: 1277-1293.

12. Nakao, T., Moriyoshi, M. and Kawata, K. 1992. The effect of postpartum ovarian dysfunction and endometritis on subsequent reproductive performance in high and medium producing dairy cows. Theriogenology 37: 341-348.

13. Olson, J. D., Ball, L., Mortimer, R. G. and Farin, P. W. 1984. Aspects of bacteriology and endocrinology of cows with pyometra and retained fetal membrane. Am. J. Vet. Res. 45: $2251-$ 2255.

14. Opsomer, G., Coryn, M., Deluyker, H. and de Kruif, A. 1998.
Analysis of ovarian dysfunction in high yielding dairy cows after calving based on progesterone profiles. Reprod. Dom. Anim. 33: 193-208.

15. Opsomer, G., Grohn, Y. T., Hertl, J., Coryn, M., Deluyker, H. and de Kruif, A. 2000. Risk factors for postpartum ovarian dysfunction in high producing dairy cows in Belgium: a field study. Theriogenology 53: 841-857.

16. Roche, J. F., Mackey, D. and Diskin, M. D. 2000. Reproductive management of postpartum cows. Anim. Reprod. Sci. 60 61: 703-712.

17. Sangsritavong, S., Combs, D. K., Sartori, R., Armentano, L. E. and Wiltbank, M. C. 2002. High feed intake increases liver blood flow and metabolism of progesterone and estradiol-17 beta in dairy cattle. J. Dairy. Sci. 85: 2831-2842.

18. Sartori, R., Haughian, J. M., Shaver, R. D., Rosa, G. J. and Wiltbank, M. C. 2004. Comparison of ovarian function and circulating steroids in estrous cycles of Holstein heifers and lactating cows. J. Dairy. Sci. 87: 905-920.

19. Shrestha, H. K., Nakao, T., Higaki, T., Suzuki, T. and Akita, M. 2004. Resumption of postpartum ovarian cyclicity in highproducing Holstein cows. Theriogenology 61: 637-649.

20. Shrestha, H. K., Nakao, T., Suzuki, T., Higaki, T. and Akita, M. 2004. Effects of abnormal ovarian cycles during pre-service period postpartum on subsequent reproductive performance of high-producing Holstein cows. Theriogenology 61: 15591571.

21. Silvia, W. J., Lewis, G. S., McCracken, J. A., Thatcher, W. W. and Wilson, L. 1991. Hormonal regulation of uterine secretion of prostaglandin $\mathrm{F}_{2 \alpha}$ during luteolysis in ruminants. Biol. Reprod. 45: 655-663.

22. Smolders, E. A., Thesingh, M. S., Vos, P. L. and Willemse, A. H. 1996. The onset of the ovarian cycle following calving. Tijdschr Diergeneeskd. 121: 610-614.

23. Thatcher, W. W. and Wilcox, C. J. 1973. Postpartum estrus as an indicator of reproductive status in the dairy cow. J. Dairy. Sci. 56: 608-610.

24. Villa-Godoy, A., Hughes, T. L., Emery, R. S., Chapin, L. T. and Fogwell, R. S. 1988. Association between energy balance and luteal function in lactating dairy cows. J. Dairy. Sci. 71: 1063-1072.

25. Wilson, S. J., Marion, R. S., Spain, J. N., Spiers, D. E., Keisler, D. H. and Lucy, M. C. 1998. Effects of controlled heat stress on ovarian function of dairy cattle. 1. Lactating cows. J. Dairy Sci. 81: 2124-2131.

26. Zulu, V. C., Nakao, T., Yamada, K., Moriyoshi, M., Nakada, K. and Sawamukai, Y. 2000. Clinical response of inactive ovaries in dairy cattle after PRID treatment. J. Reprod. Dev. 46: 415-422. 